\title{
IX. A brief examination of the received doctrines respecting heat or caloric. Read before the Askesian Society, December 1799
}

\section{Alexander Tilloch}

To cite this article: Alexander Tilloch (1800) IX. A brief examination of the received doctrines respecting heat or caloric. Read before the Askesian Society, December 1799, Philosophical Magazine Series 1, 8:29, 70-78, DOI: 10.1080/14786440008562609

To link to this article: http://dx.doi.org/10.1080/14786440008562609

曲 Published online: 18 May 2009.

Submit your article to this journal $\pi$

Џll Article views: 2

Q View related articles $\sqsubset$ 
Buffon, which is a tantalus; nor the ibis of Haffelquift, which is an ardea; nor that of Maillet, which is a vulture; but a numenius or curlew, which has not yet been named by fyftematic authors, and of which Bruce has given a figure under the name of the abou-bannès. I call it numenizus ibis, albus, capite et collo nudis, remigibus pennis htropygii elongatis, roftro et pedibus nigris.

The tantalus ibis of Linnæus, in the prefent ftate of his fynonymy, comprehends four fpecies, of three different genera:

A tantalus, the ibis of Perrault and Buffon;

An ardea, the ibis of Haffelquift;

Two numenii, the ibis of Belon;

And the ox-bird of Shaw.

The reader may judge by this inftance, and many others, of the ftate in which the Sy/tema Natures ftill remains, and of what importance it would be to free it gradually from thofe errors with which it abounds, and with which naturalifs feem to load it ftill more, by accumulating, without choice and proper examination, fpecies, characters, and $f_{y-}$ nonyms.

IX. A brief Examination of the received Doctrines refpecting Heat or Caloric. By Alexander Tilloch. Read before the Afkefan. Society, December $1799^{*}$.

$\mathbf{T}_{0}$

$O$ detail the various theories maintained at different periods, and applied to explain the phenomena to which heat gives rife in the numerous changes prefented by Nature in chemical combinations and decompofitions, would be taking up the time of this Society unneceffarily, as every member muft be well acquainted with them. I thall therefore confine myfelf to the modern doctrines on this fubject; and even with thefe I thall be brief, as my chief object is, to inquire, Whether none of the circumftances that accompany the known facts in this department of phyfics (fuch of them, I mean, as the limits I have prefcribed to the prefent effay will

* For a thort account of this Society, fee Note, P. 353, Vol. VIr. 
allow me to notice) have been overlooked? and whether, If all of them had been attended to, and the legitimate inferences been drawn from them, the theory now generally received would ever have been admitted into fcience?

The ground I am about to take may perhaps expofe me to the danger of being confidered as an innovator, or, what may be deemed worfe by fome, a fceptic as to certain opinions, rendered refpectable by the great names that have embraced and maintained them; and at the fame time extremely plaufible from the apparent facility with which they are applied to explain many phenomena that daily prefent themfelves to the eye of every attentive obferver. My only anfwer is, that $I$ am in fearch of truth; and fo decided an enemy to mere theoretical fpeculations, that I neither admit myfelf, nor with others to admit in phyfics what cannot be proved to be truth. When the human mind acquiefces on any ground fhort of this, it is either through mifconception, indolence, or pufillanimity, than which nothing has tended more to retard fcience and thackle men with prejudices, leading them to receive great names for argument, and, for demonftration, long quotations. But, to proceed, I ufe the term beat to denote that fubftance which poffeffes thofe properties, is governed by thofe laws, and produces thofe effects which fhall be immediately enumerated; and I prefer it to the term caloric * for no other reafon but becaufe the latter is employed by many to denote heat exifting in a certain ftate, in which, they fay, it may be confidered as having actually loit its original character: whereas I hold, and I even hope to convince the members of this Society, that it invariably retains the fame character, properties, and mode of action.

* The term caloric has been adopted in the new nomenclature to avoid that ambiguicy and mifconception which might, it is faid, arife from employing the fame term to exprefs a fubftance, and the fenfation produced by the action of that fubftance. By the fame mode of reafoning, all the fibffantives thould be changed in any language that has fimilar verbs. But foppofe the argument for change, in the prefent inftance, to have full foree in fone languages, it has little or none in regard to the Englifh, which employs the word warmtb to exprefs the fenfation occafioned by bear: I thall, however, ufe the terms heat and caloric indifferently.

(A) Heat 
(A) Featt is diffufed throught all the bodies in natute; wether folids, liquids, or aẻrifottin fluids.

(B) Fleat tends'to' an equtilibirinim; fo that, when by any means it is accumalated in particular fubftances, a portion is quickly given of to the furrounding bodies to bring the whole to one commont temperature. Ont the other hand, where bodies have been deprived of a portion of it, heat is given off to them by, or heat paffes to them from, the furrounding bodies, to reftore the equitibrinm.

(C) Solids, by the addition of heat, affume the form of liquids, and liquids the atriform ftate. On the other hand, gafes, by an abftratiotiof of heat, become liquids; and liquids, folids.

(D) The dimentfitis of boolfes are enlarged when heat is poured into them, and vice verfa.

The laws we have enumerated are general, and the objections that may be ftaten againft the trith of any of them for few, and fo eafily obviated, that they cannot affect any inference drawn from them. The apparent exceptions relate chiefly to the change of volume in fome particular fubftances when paffing from the liquid to the folrt form, or the contrary. Water, for inftance, in paffing into the ftate of ice, afumes a larger volume, though heat is then paffing out of it. The fubftance, however, is only apparently enlarged: In freezing, the water afluties a cryltalline form; the cryttats, fluting in every direction, crowd' againft, and, as it were, jofte each other, cauting vacuities; which cónftitute ro real part of the matter. We may compare' this phenomenon to what takes place in a bundle of chips of wood, which will always; however clofely packed, occupy an apparently larger fpace than the fame weight of ligneous matter as arranged by nature in the tree. Another apparent exception may be noticed in clay, which diminifhes the more in bulk the greater the quantity of heat poured into it: but here there is a mifnomer-it is not clay, but a nixture of clay and water that is diminithed in bulk. The water is driven off; and, where there is a dininution of matter, a reduction of volume muft follow. Clay is therefore not an exception to 
the general law-drive all the water out of it, that is, convert it into glars, and it then obeys the general law.

We thall firft attend a little to the operation of the foregoing laws in fome given cafes; and afterwards examine the doctrines which have been eftablihed from the phenomena obferved to accompany them:

If two bodies of the fame nature, unequally heated, be brought into contact, the heat will diffufe itfelf equally through them, and the quantities in each will bear the fame proportion to each other as the maffes themfelves; but, if the bodies differ in kind, though equilibrium take place, and each indicate the fame temperature, yet the proportions of heat in each will not be as the maffes, but vary according as the bodies differ.

(E) This property of bodies to hold different quantities of heat, even when that fluid is in a fate of equilibrium, Dr. Black calls the capacity of a body for brat; the quantity itfelf he calls jpecific beat. The diftinction is perfectly philofophical, nor need the terms be objected to; but they thould be accurately defined, that they may never be employéd to convey ideas different from the facts that gave rife to their adoption.

That the fenfe in which we underftand and ufe the terms may be clearly conceived, we thall fubftitute another fubftance for heat, all other circumftances being as before. If two fubitances of the fame kind (twa pieces of chalk), unequally wetted with water, be brought into contact, the one iwill give off water to the other (or the one will abforb water from the other) till the quantity in each be as tbeir majes. If two boulies different in kind (chalk and wood) be thrown into water, the quantity they will each take in will be as thear capucities: this will alfo be the cafe if, inftead of throwing them into water, we fufpend both in the fame damp atmofphere; and the quantity in each, whether received by inumerfion in water or in the atmofphere, is fferific. The latter term mut be thus confidered, otherwife we thall lead ourfolves into cror; for there is at leaft as great a difference between the extremes of the general temperature in fummer and in winter as there is between a noift, and a comparatisely dry (but yet moift) atmofphere.

Vol. YIII. 
Some philofophers tell us that tbe caufe of this phetio. menon of different bodies requiring different quantities of cabric to indicate the fame temperature' (or, in other words, the caufe of their having different capacities for heat) arifes from the different degrees of affinity which different bodies poffefs for licat! Is this an explanation ?-Different bodies hold different quantities of heat, bicaufe they bave diffirent capacitics: - Different bodies hold different quantities of heat, becaufe thry bave different affinities!-yet we are to confider the one term as expreffive of a property, and the other as expreffive of ibe caufe of that property! Is this confiftent with that accuracy and precifion which thould prevait in the language of fcience?

But this is not all. Heat is confidered as exiffing in two diftinct ftates; free, and in chemical union. When heat is in equilibrio in any place; in other words, when a body is in equilibrio with the bodies which fúrrotnd it with refpect to its heat [that is, has received hèat from the common ftock proportioned to its capacity] ; that quantity which it contains is termed latent heat or 'caloric; comlincd caloric; brat in cbemical union. We are told that in this ftate it is not perceptible by any external fign or organ of fenfe; that it does not affect the thermometer, but remains quiefcent in thofe bodies of which it conftiutes a principle ; and that it is then, more or lefs, in a ftate of confinemert.

Is the heat in any body termed latenit becaufe the body has not a capacity to receive more? No; for if, by any means, an addition be made to the common ftock of a prefcribed fyftem of bodies, each individial fubftance will fitill provide lodging for a thare of the added quantity, proportioned to its capacity, in relation to the capacity of the reff. It fhould be obferved too, that, let the common temperature be what it may, if heat be in equilibrio, the portion in each body is, by fome at leaft, held to be latent, in contradiftinction to what they term free biat. Hence it follows, that the quantity of taicht beat in a given body differs in different feafons of the year; for heat may be in equilibrio in any fyttem of bodies in fummer as well as in winter. An affemblage of different bodies, in equilibrio as to caloric, in Jamaire, 
Jamaica, the quantity in the whole is latent, and in each fpecific and latent: the fame holds with regard to a fyftem of fubltances in England in the month of January: The heat in both cafes is latent. If the one fytem of bodies could be tranfported to the other in a moment, and placed in contact with it, a portion of that heat which was latent in Jamaica, would be counted fenjable heat in London! This is exactly where the doctrine lands us when wiewed generally; and yet we are to confider heat as baving two diftinct modes of exiftence! But let us take a clorer view of it :

When by the paffing of a folid body into a fluid form the furrounding atmofphere is found to have loft heat, this heat, they fay, has not been nerely abforbed by the fub. fance that has become fluid, but has become latent in it. When a liquid paffes into the aëriform ftate, the fame phenomenon accompanies the change, and alfo the fame affertion; and the doctrine is meant to convey the idea that heat has not only been changing its place, but has itfelf undergone a change as to its ftate, its properties, and mode of action.

It is a generally received axiom, that no more caufes. hould'be admitted in phyfics than what are true and fufficient to account for the phenomena. Let us inquire whether this sxiom be nat violated in the cafes ftated, when re? courfe is had to the doctrine of latent, as diftinguined from free, heat, to affit in explaining the phenomena.

The dimenfions of bodies are enlarged when heat is poured into them (D). The primitive molecula (independent of the heat) of which the bodies are formied, are forced farther from each other by the interpofed matter of heat. Continue the action of the fame caufe, their cohefion will be deftroyed entirely (C), and they will be diffufed throngh the predominating fubttance (heat), as the particles of faline fubtances diffufe themfelves through water when diffolved in that liquid. In the cafe juft put for illuftration, wha. ever fuppofes the water to have undergone any change as to. its effence or properties, whether direetly poured upon the faline fubftance or furnithed to it by the atmofphere.

In chemiçal combinations it is admitted that we cannot, L 2 a prioris 
a priori, determine the properties of the compound from a previous knowledge of thofe of the ingredients. Every fubftance has, for one of its properties, a capacity for beat. If twr be united chemically, the capacity of the compound for heat may not be that of the fum of the capacities of the ingredients for the fame fubitance. Indeed it feldom or never turne out fo. If by any prosels then we change the capacity of two or more bodies; or, by uniting them, produce a third, whofe eapacity for heat is greater than the fum of that of the ingredients, this new compound muft demand from the common ftock of heat diffufed through the atmofphere and other neighbouring fubftances (A) an additional portion. Is there any thing in all this to lead us to the notion that the paffage of heat from the atmofphere, or other contiguous bodies, into the new compound, is the operation of any other than the general law by which heat tends to an equilibrium among all the bodies in a fytem (B), and diffufes itfelf among them in proportion to their capacities for heat (E)? Is not the operation of thefe laws fufficient to explain the phenomena without the aid of any others?

But, befides, is it not a general faet, in all cafes where a eapacity for a greater quantity of heat is produced in a compound thain the fum of the capacities of the ingredients, that the fun of the volume of the compound is greater than that of the ingredients? And is it not equally true, that, when ingrediente, before in union, are found, on being feparated, to have acquired capacities for heat, whofe fun is greatcr than was that of the body in which the ingrediente; were united; the fum of the volume of the ingredients is grcater than the volume of the compound was * Can it be correct to fay that it neither affects our fenfes, nor is cognifable by any external fign! when we can fee with our eyes, its effect in the increafe it has made in the volume of

At the moment of writing I do not recollect a fingle cxception. In cafes where cryfallifation is concerned there my he fome apparent ones, as in the cafe of water and jes ; but theie, will not affect my argument. It is encugh for me $\mathrm{tl}$ at the fira hold generally in the calcs to which the doetrine of latent heat is afplied-an effect perfectly conformable the the gonetal law (D), and alio cognigule by ukf firfis. 
the compound fubftance before us; or in the fum of the maffes of two or more fubftances over that of the compound from which they were feparated?

Again-When gafes pars into the form of liquids, or li. quids into the folid ftate, heat is found to pafs from them into the atmofphere, "the heat that was latent in them before now becomes fenfible." Was it not cognifable ber fore? It ought not to have been fo when latent. I find; however, that the volume of the body from which it has been feparated is now less than before; and this is exactly what ought to take place from the general laws, not only of heat but of matter-a fubftance, heat, has been feparated from a body in which it formed a part of the mals or volume, and the remaining mafs is diminifhed.in bulk.

Let us, however, alter the mode of expreffion. A body, no matter by what means, is reduced into a lefs volume; it is fo conftituted as to admit of this effect being paffed upon it; for one of its ingredients, heat, is a fubtile fluid which may be diflodged; nay, will even run out, when the capacity of the body which held it is leffened. It is no way ftrange, in this cafe, that a fluid poured out of its recipient, and which, by its tendency to equilibrium, muft diffufe itfelf through the furrounding bodies in proportion, to their capacities to receive it, fhould make itfelf manifeft to our fenfe of feelinǵ, we being immerfed at the moment in one of the neighbouring fubftances, the atmofphere, which affords a lodging for a portion of the diflodged heat, and ferves to tranfport other portions of it to all the neighbouring bodies. Nor is it ftrange that a fubftance which, while it formed an ingredient in the body from which it has been removed, conftituted alfo a part of its volume, fhould, when it paffes into another body, mercury in a glafs tube, caufe an increafe in its volume proportioned to the quantity that has paffed in.

It conftituted fenfyble bulk in the firf body, and was latent beat; it confitutes fenfible bulk in the fecond body alfo, but there it is fenfible beat!! Is there no abfurdity in all this?

Heat in thofe combinations, in which the term latent is employed, not cognifable by our fenfes! Is it not obvious 
from the preceding ftatement that this is a miftake? Be* fore the heat paffed ont of its then' combination it made a part of the, volume which we contemplated with our eyes, and the proportion that this part bore to the whole might, in many cafes, be determined by actual meafurement. ' Is fenfible heat, or rather heat in fuch combinations as it is in when that term is ufed, cognifable by aný other means?

To me it would appear as correct, when, by any power, the capacity of a veffel filled with a liquid (water) is diminifhed, to fay that the portion of liquid thereby ejected is fet at liberty; meaning thereby that it has undergone an effential change as to its form, properties, or mode of exiffence ; as to fay, when the volume of a fubftance containing heat is abridged, and a proportionate quantity of the heat is difodged, that the heat, fo dillodged, has undergone any fuch change.

The, fact in my opinion is, the fubftance in which the caloric refided has undergone the change, where there is $x$ change; not the heat: or, if it be changed, the change is of that kind which pafies upon a brick or any other body when we move it from one room to another. This, I think, muth be pretty clear from what we have already ftated; but 1 hope to make it fill more fo by examining a particular cafe or two which have been made to ferve for a foundation, as it were, for the doctrine which I oppofe.

[To be continued,]

\section{NEIV PUBLICATIONS.}

An Account of the Iri.'ses or Coronec abicb appear arownd, and contiguous to, the Bodic's of the Sun, Moon, and otber Luminous Objects. Cadell and Davics, 1799: 46 pages, With One Copperplate.

TIIS treatife is by the author of the Obervations on the Inflevions of Ligbt, of which a fhort account was given in the Philofophical Magazine for September. In making thefe obfervations, that ingenious gentleman perceived that 